\title{
一般用医薬品販売制度改革に対する薬学生の意識調査
}

\author{
奥澤紘子，鵜飼加奈子，武藤奈々美，草間美嘉， \\ 中村智德, 上野光一 ${ }^{*}$ \\ 千葉大学大学院薬学研究院高齢者薬斉学研究室
}

\section{Survey of Pharmacy Student Views on Revision of Over-The-Counter Drug Sales System}

\author{
Hiroko Okuzawa, Kanako Ugai, Nanami Muto, Mika Kusama, \\ Tomonori Nakamura and Koichi Ueno* \\ Graduate School of Pharmaceutical Sciences, Chiba University
}

\author{
$\left[\begin{array}{l}\text { Received February 20, } 2008 \\ \text { Accepted June 11, } 2008\end{array}\right)$
}

From A pril 2009 onwards, the over-the-counter (OTC) drug sales system will be deregulated in accordance with the re vised Pharmaceutical Affairs Law. There will be two major changes. As the first one, the risk classification of OTC drugs will comprise 3 classes and as the second, new qualifications for the registration of drug sellers will be established. The aims of this study were to investigate the views of pharmacy students concerning the revision of the OTC drug sales system and to reflect the results obtained in pharmaceutical education programs. To do this, small group discussion (SGD) was included in the college class program for 82 undergraduate students in the 3rd year of a 4-year course at Chiba University and they were given 2 questionnaires - one before the SGD and one after it.

The questionnaire found that $95 \%$ of the students knew the term" OTC drugs" and $73 \%$ thought that such drugs were easy to obtain. Further, while $72 \%$ agreed with the new risk classification for OTC drugs, 52\% opposed the establishment of new qualifications for the registration of drug sellers. Through the SGD, they realized that pharmacists need to acquire a special knowledge of OTC drugs and skill in providing appropriate information on their safe use. Overall, the results suggest that future pharmaceutical education programs need to incorporate training designed to achieve a comprehensive knowledge of drugs and enhance communication skills.

Key words — over-the-counter drugs, revised system for sale of OTC drugs, pharmacist, pharmaceutical education, small group discussion, communication skills

\section{緒 言}

平成 15 年 6 月に閣議決定された「経済財政運営と構 造改革に関する基本方針 2003」において，医薬品販売 体制の拡充として, 利用者の利便と安全の確保について 検討し安全上，特に問題がないとの結論に至った医薬品 すべてについて，薬局薬店に限らず販売できるようにす る，と明記された(経済財政運営と構造改革に関する基 本方針 2003 http : / / www .kantei .go.jp/jp/singi / keizai / kakugi/030627 f.html\#2-1). 炎の後さまざまな審議を経 て, 平成 18 年 6 月の衆議院本会議において薬事法改正 案が可決成立し, 平成 21 年度から施行されることと なった .
この改正案では違法ドラッグ対策の強化とともに，一 般用医薬品の販売制度見直しが大きな目的とされてい る.一般用医薬品販売に関し，一般用医薬品のリスクの 程度に応じた分類や情報提供と相談体制の整備，医薬品 販売に従事する薬剂師とは異なる新たな専門家を設ける ことが大きな变更点である．一般用医薬品の分類と光の 程度に応じた情報提供のあり方については，医学・薬学 等の専門的知見を有する学識経験者により構成される 「医薬品のリスク程度の評価と情報提供の内容等に関す る専門委員会」により検討された(医薬品販売制度改正 検討部会報告書 平成 17 年 12 月 1 日 厚生科学審議会 http : / www.mhlw.go.jp/shingi/2005/12/s1215-9a.html) . 第 1類は「一般用医薬品としての市販経験が少なく，一 般用医薬品としての安全性評価か確立されていない，ま 
たは，一般用医薬品としてリスクが特に高いと考えられ る成分を含むもの」か該当し，販売時に積極的な情報提 供を必ず行うように義務づけられた .また，第 2 類は「ま れにではあっても，日常生活に支障をきたすお光れがあ る成分を含むもの」か該当し，販売時の情報提供は努力 義務とされた . 第 3 類は「日常生活に支障をきたすほど ではないが, 副作用等により身体の変調・不調を生じる お光れがある成分を含むもの」か該当し，情報提供は法 令上規定するほどではないとされた . これらの分類を踏 まえ，購入者が判別しやすいような外箱の表示や陳列方 法の改善が求められている.さらに一般用医薬品を販売 することができる専門家として，薬剤師に加え新たな資 格として「登録販売者」が新設された .この資格は販売 実務経験のある有資格者が都道府県において実施される 試験に合格することで与えられ，第 2 おび 3 類の一般 用医薬品販売が可能となる．すなわち，これまで店舗ご とに与えられていた販売登録が , 今後は個人に対する資 格として与えられることになり，現在の薬種商販売業， 配置販売業, 特例販売業の資格要件は登録販売者として 統合されることとなった .

以上, 最近の法改正を巡る現状を踏まえ, 薬学部学生 の本制度改革に対する考え方を把握し，今後の薬剂師 6 年制教育への活用を目的として意識調査を行った .

\section{方法}

千葉大学薬学部 3 年次在籍(旧 4 年制課程)の学生 82

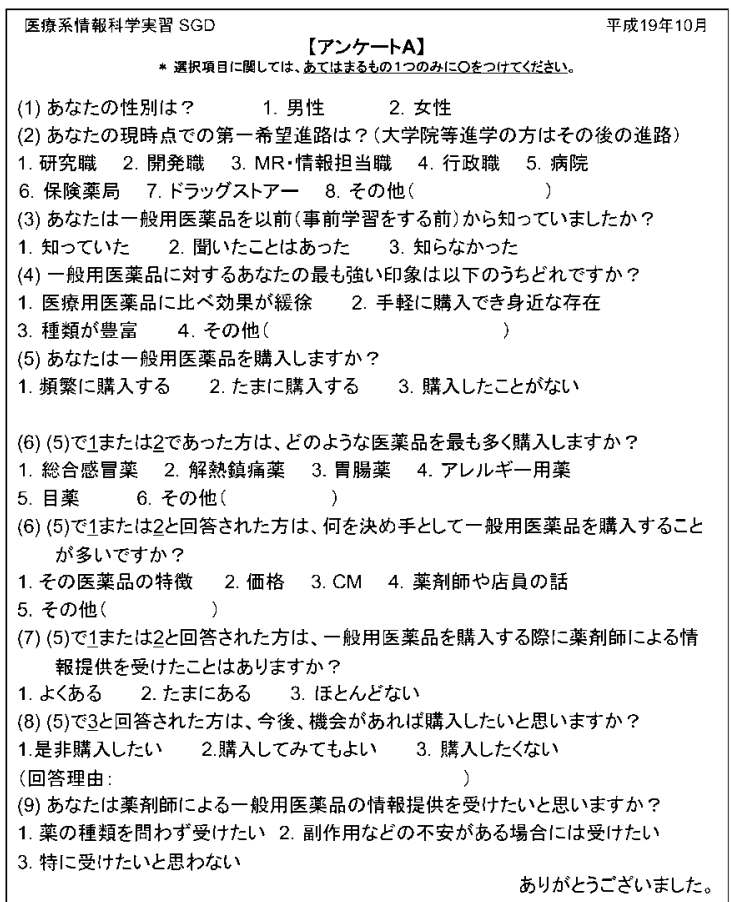

图 1. 選択式意識調査(アンケート A)
名(男性 40 名, 女性 42名)に対し, 薬学部医療系情報科 学実習の一環として行われている small group discussion (SGD)において「一般用医薬品販売制度改革について」 というテーマを取り上げた．SGD および炎の前後に二 種類のアンケートA およびB を実施した(図 1, 2).SGD では，6人もしくは 7 人の班に分かれてあらかじめ司 会，書記，発表者を決めたうえで，テーマついて各自事 前に調査した内容をもとに 90 分間議論し, 光の内容を 全体討論で発表した .なお，議論の進行補助，記録の目 的で各班にチューターとして学部 4 年次もしくは修士課 程在籍の学生を 1 または 2 名配置した．SGD の結果に は全体討論の内容を要約して記載した．アンケートで は，SGD 開始前に一般用医薬品に関する選択式意識調 査(アンケート A)，SGD 終了後に本制度改革や今後の薬 剂師の役割等に対する記述式意識調査(アンケート B)を 行った . アンケートB(4)および(5)において学生が挙げ

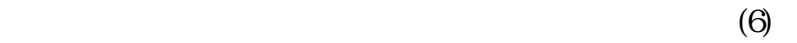
(7)，(8)については趣旨が似ているものを項目として統 合した後に集計し，結果には学生の意見のうち多かった ものを表記した .なお，アンケートは無記名とし，複数 回答は光れ光れを集計した。

\section{結＼cjkstart果}

1. アンケート A の結果

SGD 実施前に, 対象者の背景と一般用医薬品に対す る理解度を知る目的で選択式意識調査アンケートAを

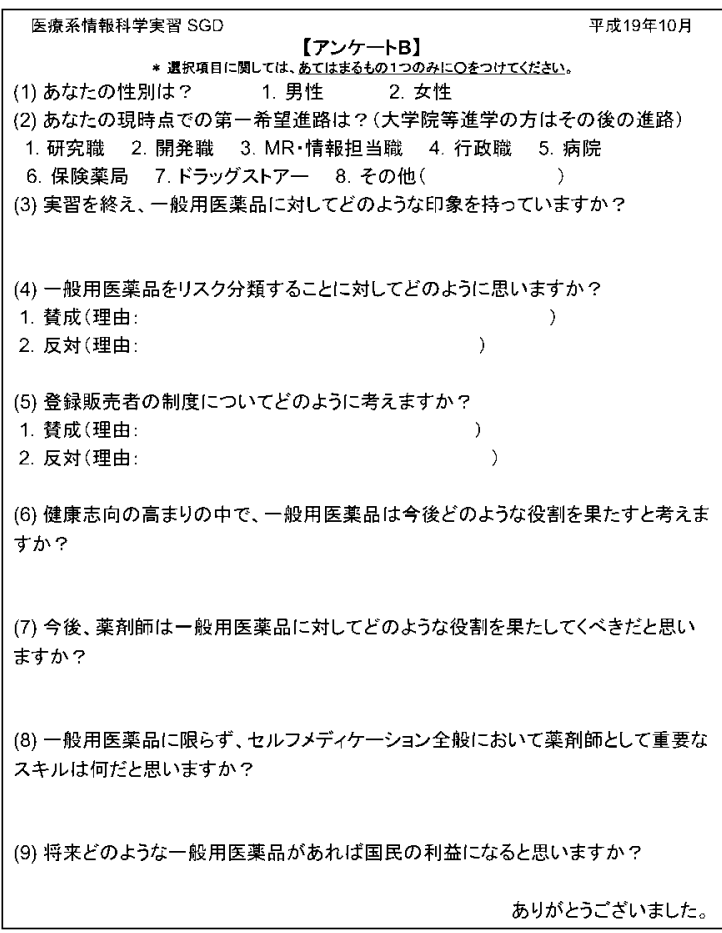

図 2 . 記述式意識調査(アンケート B) 
行った.なお，アンケートA の回収率は $100 \%(n=82)$ であった . 产の結果，学生の卒業後の進路希望について は研究職 $47 \%$, 開発職 $15 \%, M R \cdot$ 情報担当職 1\%，行 政職 $9 \%$, 病院 $15 \%$, 保険薬局 5\%, 弚の他・未回答 8 \%であった . 一般用医薬品について「知っていた」もし くは「聞いたことはあった」と答えた学生は 95\% を占 めた(図 $3 \mathbf{A})$. 光の印象については, 「手軽に購入でき る」と答えた学生が 73\%, 以下,「効果が緩徐」(22\%). 「種類が豊富」(4\%)と続いた(図 3 B ) . また，91\% の学生 が一般用医薬品を購入した経験があり，光の種類は解熱 鎮痛剤から目薬まで多岐にわたっていた(図 3 C ，D) . 一般用医薬品を購入する際の決め手としては「关の医薬 品の特徵」(50\%)および「薬阂師や店員の話」(11\%)が上 位を占めた(図 3 E) ．また，薬阂師による情報提供が「よ くある」「たまにある」と答えた学生が $39 \%$ であった のに対し，「ほとんどない」と答えた学生が $58 \%$ を占め た(図 $3 \mathbf{F})$.

\section{Small Group Discussion}

テーマについて制度改革の利点, 問題点および改善策 についてさまざまな視点からの議論がなされた . まず， 制度改革の利点として消費者側に立って考えた場合，登 録販売者がコンビニエンスストアやスーパーに配置され ることで 24 時間薬か購入でき利便性が増すことや，リ スク分類による陳列がされることによりリスクを認識し やすくなるといった点が挙げられた . また，企業側に 立って考えた場合，第 2 おひび第 3 類の医薬品を販売す るとき，薬剤師ではなく登録販売者を雇用することによ り人件費削減が期待できるという点が挙げられた．薬剤 師側に立って考えた場合には，医薬品に関する知識を持 つ専門家が増えることにより調剂業務に専念できるとい う点が挙げられた . しかし一方で, 薬剤師の資格がなく ても販売できる医薬品があることにより薬剤師の雇用が 減少する懸念が挙げられた . また，多くの班において， 登録販売者が薬を扱う資格として適当かどうかという議 論がなされた，登録販売者の資格要件を考えると，学生 は試験問題の難易度や実務経験の判断に疑問を感じ，消 費者から求められた際に薬の飲み合わせや消費者個々の 状態に応じて適切な判断と情報提供ができるのかといっ た問題点が挙げられた .

これらの問題点に対する改善策も各班から挙げられ た．まず，登録販売者が消費者の疑問に答えられない場 合に，すぐに薬剤師と連絡を取れる体制を整備すること の必要性が挙げられた．登録販売者の質を維持するため には，資格を更新制にすることや講習会受講を必須とす るなどの意見が挙げられた．また，適切な情報提供を実 施するために，あらかじめデータベース化されたものを 利用して情報提供をすることや，会計時にバーコードを
読み込むと同時に光の医薬品の情報が画面に現れるシス テムを利用することが提案された . 一律の情報提供だけ でなく個々の消費者にあった情報提供を実施するため に，相談密口を設けることやお薬手帳を一般用医薬品に も活用し，さらにICカード化してより普及しやすくす るなど, コミュニケーションを取りやすい雰囲気作りが 必要であるという意見が挙げられた .

\section{3.アンケート B の結果}

SGD 終了後に一般用医薬品販売制度改革に対する印 象や薬剂師のかかわり方について，より詳細な記述式の アンケートB を行った .なお, アンケートB の回収率

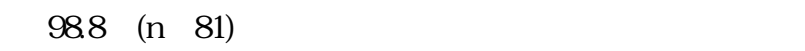
対する印象は「身近あるいは手軽で便利」と答えた学生 が 32\% である一方，「使い方や副作用に注意するべき」 (32\%)，「専門家による介入や説明が必要」(5\%)および 「消費者の意識や管理能力が必要」(3\%)という意見が挙 げられた(図 $4 \mathrm{~A})$. 一般用医薬品のリスク分類について 賛否を尋ねたところ，「わかりやすい」,「リスクを認識 することは重要」などの理由により賛成と答えた学生が $72 \%$ ，「分類方法に対する疑問」,「低リスクと分類され た医薬品に対する軽視への危惧」の理由による反対が 22 \%であった(図 4 B) . また , 今回導入されることとなっ た登録販売者制度に対する賛否を尋ねたところ，「利便 性の向上」,「薬斉師がより専門的な業務に従事できる」 などの理由による賛成が $42 \%$ であったが，このなかに は資格取得のための試験内容など登録販売者の質を上げ ることが必要であるという条件付きの賛成意見がみられ た(図 4C) .さらに，登録販売者制度に反対する意見が $52 \%$ みられたが，光の理由には「薬剂師の役割や職場 の減少に対する危惧」,「登録販売者の能力への疑問」, 「薬学部新設による薬剂師増加傾向との矛盾」などが挙 げられた . また , これらリスク分類についての賛否およ び登録販売者制度についての賛否においては, 進路希望 別で差はみられなかった . 健康志向が高まるとされる今 後の一般用医薬品が果たす役割については, 「セルフメ ディケーションの一端を担う」,「身近で家庭常備薬の存 在」などを理由に増加するとの意見が多く見受けられた (図 4D) ．光の一方で，「役割は増加するが薬の乱用傾向 につながる」，または「現在と変わらない」という意見 がみられた．一般用医薬品に対して薬剤師の果たしてい くべき役割については，「情報提供」が最も多くを占め， 次いで「知識をつける」という意見が続いた(図 $4 \mathbf{E}$ ) . ただし，知識に含まれるものとしては，薬学部で培う知 識は医療用医薬品についての知識がほとんどであるた め,「一般用医薬品についての知識を増やすべき」とい う意見と，より深く適切な情報提供を行うために「医 療・一般用医薬品を含めた全般的な知識をつけるべき」 
A．一般用医薬品を以前から知っていましたか

$(n=82)$

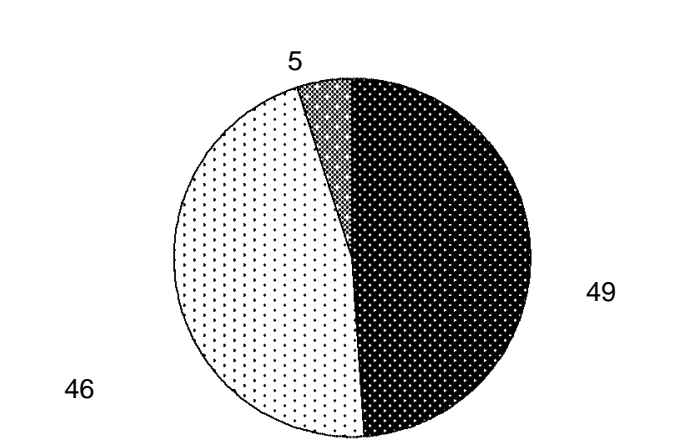

C．一般用医薬品を購入しますか

$(n=82)$

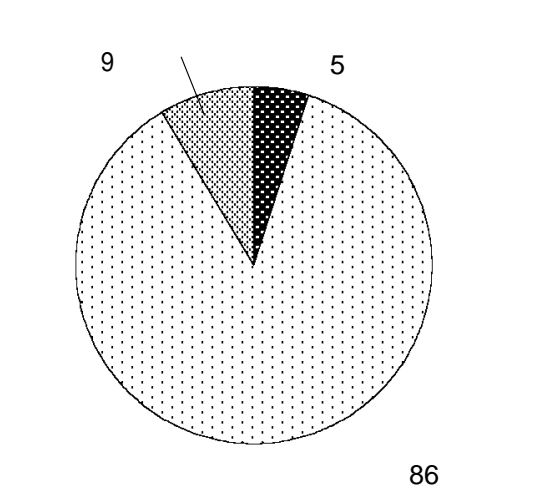

E ．何を決め手として

一般用医薬品を購入することが多いですか

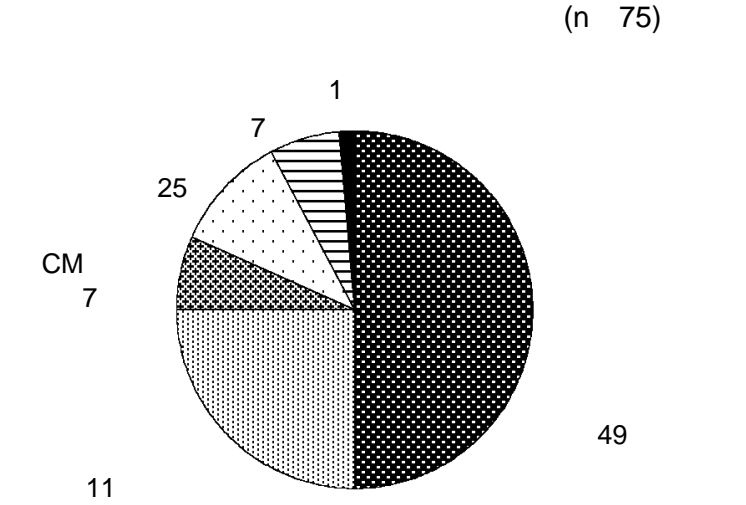

B ．一般用医薬品に対する

あなたの最も強い印象はどれですか

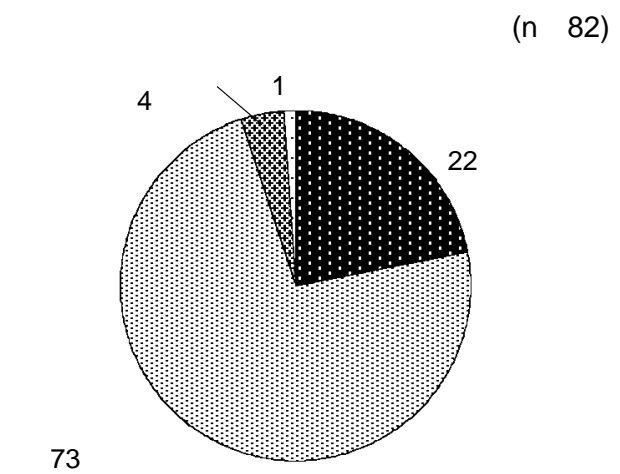

D . どのような医薬品を最もよく購入しますか

$(n=79)$

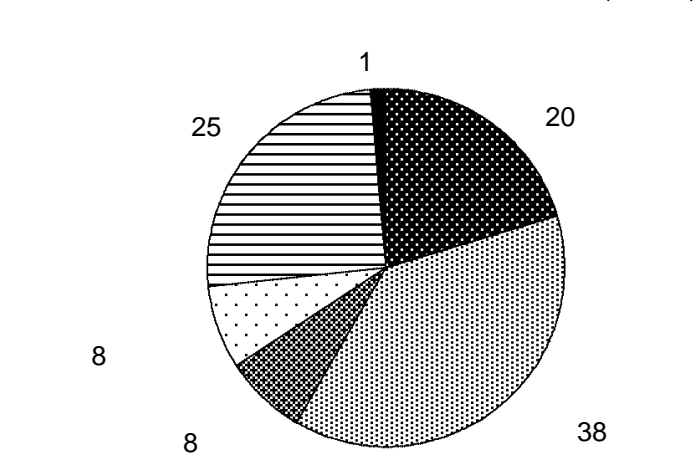

F . 一般用医薬品を購入する際に薬剤師による 情報提供を受けたことがありますか

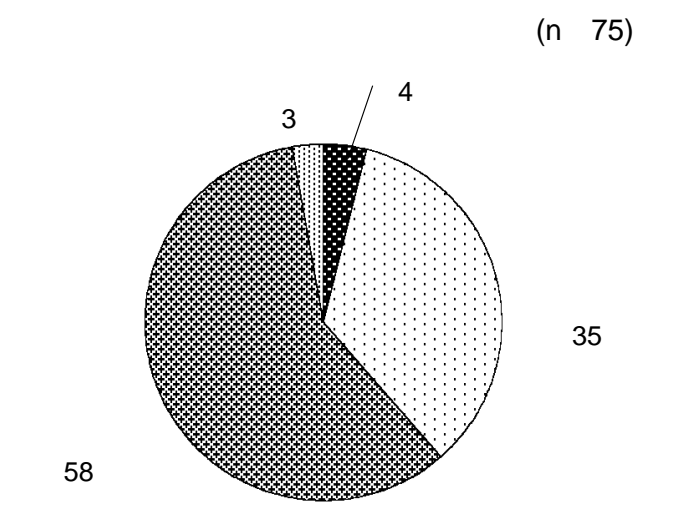

図 3.アンケートA 結果

という二種類の意見がみられた . 最後に , セルフメディ ケーション全般において薬斉師として重要なスキルを尋 ねたところ, 情報提供や気遣いのある対応を含む「コ ミュニケーション能力」が最も多く，次いで「知識」で あった(図 4 F) .

\section{考察}

平成 21 年度からの制度改革へ向けて本学薬学部生が
一般用医薬品販売制度をどのように考えるかについて把 握し, 今後の薬学部 6 年制教育への活用を目的として， 学生実習の一環として一般用医薬品販売制度改革につい ての意識調査を行った .

アンケートA では, 学生の一般用医薬品に対する理 解度を簡便に認識することを目的として選択式の意識調 査を行った，光の結果，学生が一般用医薬品を認識して おり実際購入する頻度も多いことが明らかになったもの の，一般用医薬品購入の決め手として「炎の医薬品の特 
A ．一般用医薬品に対して どのような印象を持っていますか

$(n=98)$

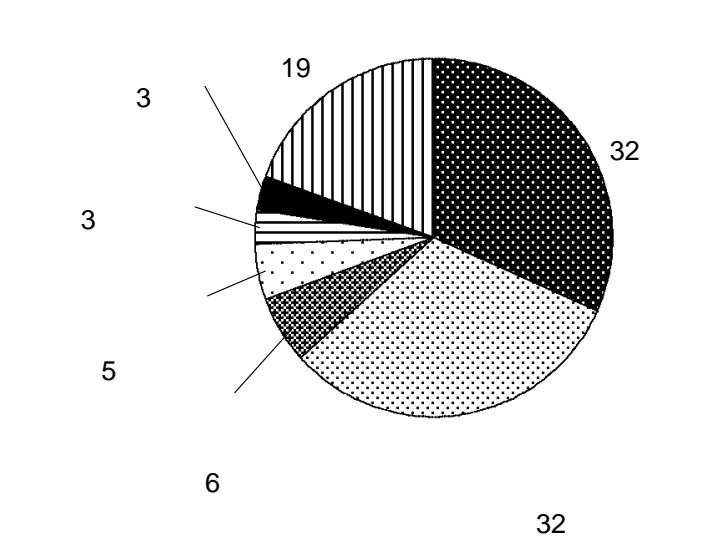

C . 登録販売者制度についてどのような考えます か

$(n=81)$

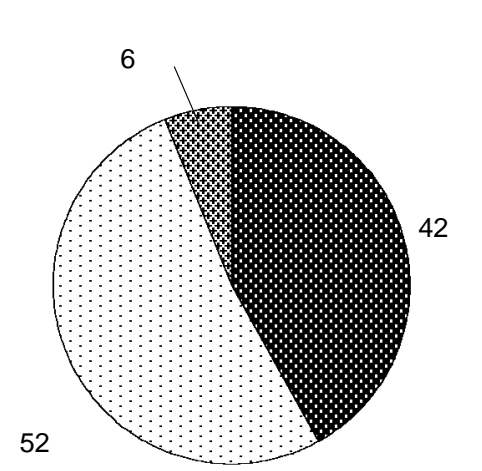

E . 今後, 薬剤師は一般用医薬品に対してどのよ うな役割を果たしていくべきだと考えますか

$(n=90)$

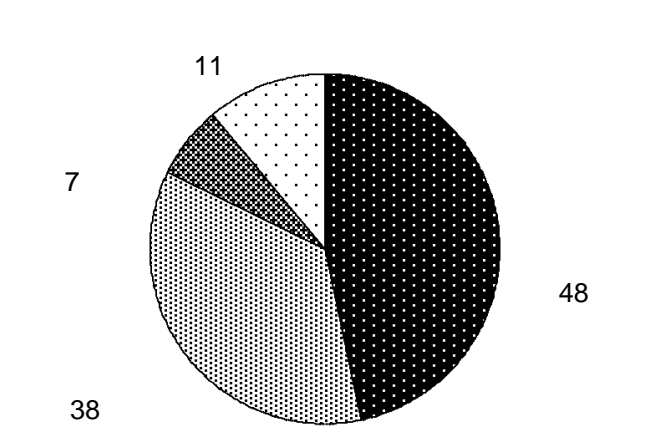

B．一般用医薬品をリスク分類する ことに対してどのように思いますか<smiles></smiles>

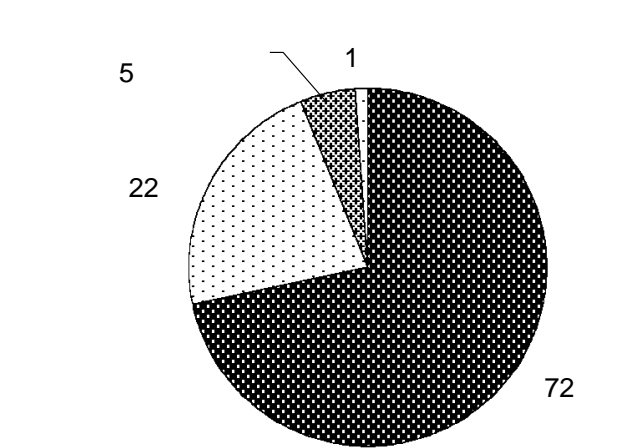

D . 健康志向の高まりのなかで一般用医薬品は 今後どのような役割を果たすと考えますか

$(n=83)$

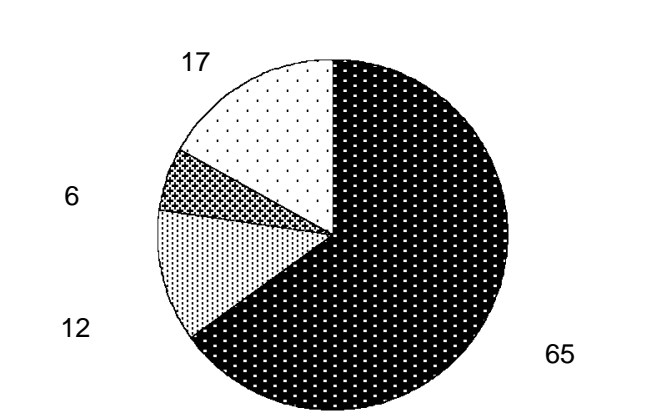

F．一般用医薬品に限らず，セルフメディケー ション全般において薬剤師として重要なス キルは何だと思いますか

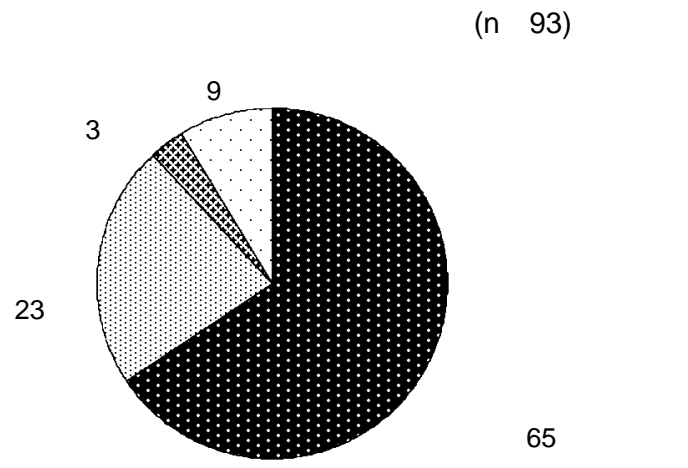

図 4.アンケートB 結果

徵」や「価格」を挙げる学生が多く，薬剂師による情報 提供が「ほとんどない」と答えた学生が半数以上を占め た。これまでに一般消費者に対して矢野経济研究所が実 施した一般用医薬品販売に関する意識調査では, 一般用 医薬品が「手軽(便利)」(93.4\%)との意見が圧倒的に多 く，一般用医薬品を「よく使用している」または「たま に使用している」ことが示されており(医薬品販売規制 緩和に対する消費者意識・ニーズ調査 2003 年 11 月 28
日 矢野経済研究所 http://jfa.jfafc.or.jp/pdf/kiseikanwa.pdf)，今回の結果と似た傾向が報告されている.ま た，同調査では一般用医薬品を購入する際に店員から力 ウンセリングやアドバイスを受けた経験について「ほと んど受けない・経験がない」が全世代では 29.5\% であつ たが , 年齢別で 20 歳代についてみると「経験がない」 が突出して高いと報告されている. 今回の調査において も $58 \%$ の学生が薬斉師による情報提供が「ほとんどな 
い」と答えていることから一般用医薬品販売における情 報提供の現状には年齢の影響も含まれると考えられる .

SGD では，事前に調査した知識をもとに，「一般用医 薬品販売制度改革について」というテーマで議論を行っ た . 本制度改革について消費者, 雇用者および薬㓢師の 立場からの利点や問題点が高い頻度で挙げられた . 全体 の傾向としては, 主に消費者の立場から一般用医薬品が リスク分類される点や身近に医薬品を購入しやすくなる 点が利点として挙げられ, 問題点としては登録販売者の 質についての言及が多かった . 登録販売者の質を懸念す る意見のなかで, アンケートA において一般用医薬品 が手軽に購入できるという利点がある反面，リスク分類 による安全性への是非に関する討論がなされた .このこ とは昨今の一般用医薬品を取り巻く国内外の情勢による ところが大きいと考えられる．すなわち，国内での規制 緩和の一方，海外では一般用医薬品の副作用が問題と なっている．アメリカにおいては，2007 年にFDA が咳 止め・かせ薬が死因であると判断された生後 6 力月以下 の幼児死亡例 3例が特定されたと報告した(医薬品安全 性情報 Vol.5 No.02 2007/01/25 http: //www.nihs.go.jp/ dig/sireport/weekly 5/02070125.pdf) . ぞの後, FDA は 2008年 1月に生命にかかわる重大な副作用が起こり得 るとして，2歳未満の乳幼児に市販のかぜ薬や咳止め薬 を飲ませるべきではないとする勧告を発表した(FDA News January 17, 2008 http://www.fda.gov/bbs/topics/ NEWS/2008/NEW 01778.html) . また, 国内においても， 2003 年に一般用医薬品のかぜ薬との因果関係を否定で きない間質性肺炎が報告され，厚生労働省は関係企業に 対して使用上の注意の改訂と薬局等への情報提供を指示 した(医薬品・医療用具等安全性情報 191 号 http： www.mhlw.go.jp/houdou/2003/07/h 0731-1.html) .こうし た一般用医薬品のかぜ薬等は, 今後, 国内において登録 販売者か販売でき情報提供が義務ではない第 2 類医薬品 に分類されることになっている.販売量や使用法などが 異なるため単純な比較はできないものの，一般用医薬品 のリスク分類のなかで登録販売者が販売できる第 2 類医 薬品による副作用の可能性は十分にある.SGD では風 邪薬や解熱鎮痛斉が第 2 類医薬品に分類されていること に不安だと考える学生がいた . 今回の SGD では学生が 一般用医薬品についての事前の調査過程でこのような現 状を認識した結果，安全性への考慮が積極的に討論され たものと考えられる .

アンケートBでは一般用医薬品販売制度改革に対す る印象や薬剂師の役割, 能力について，SGDにより考 えたことを把握する目的で記述式の意識調査を行った .

一般用医薬品に対する印象に関しては，SGDを行う 前に実施したアンケートA の選択肢に含まれていた身 近および便利であるなどの内容に加えて，SGD で討論
された医薬品の安全性や専門家の介入の必要性等の記述 がみられた ここのことから，SGDにより一般用医薬品 に対する意識の変化が生じたと考えられる．すなわち， SGD で一般用医薬品販売について薬剤師の立場から議 論したことにより，一般用医薬品が身近で便利であると いう消費者側の立場で考えた印象だけでなく，薬斉師側 の立場で考えた安全性への配慮の必要性に関する意識が 生じたと考えられる．アンケートBより，一般用医薬 品が身近になり关の役割が今後増加すると考えている学 生が大半を占めていた . 消費者が一般用医薬品販売にお いて薬阁師に期待していることは「医薬品の選択」が圧 倒的に多いという現状がある1 . 日本 OTC 医薬品協会が 実施した一般消費者の意識調査におけるセルフメディ ケーションに対する認知度は, 「内容を詳しくまたはあ る程度知っている」という「内容の認知度」が $29.9 \%$ ， 「言葉だけは聞いたことがある」という「言葉の認知度」 も含めると $65.6 \%$ になる(大衆薬に関する「消費者意識 報告書」第 31 回 2006年 12 月 日本大衆薬工業協会 http : //www.jsmi.jp/research/ishiki_31/31.pdf) . この数字 は以前より増加しており，今後，一般用医薬品の利用度 が増加することが予想され，需要は増大すると考えられ る. 兴の一方，同調査では一般用医薬品について「種類 が多くて選びづらい」 $14.1 \%$,「薬阂師が常駐して詳し く説明してほしい」 $7.7 \%$ という現状があることも明ら かになっている．このような期待に応えるために, 薬局 薬店では薬阂師および登録販売者が適切な医薬品選択の 情報を与えるための適切な知識を豊富に持っている必要 があり，新しい医薬品が次々と登場する市場では常に最 新の情報を把握する必要がある . 今回の実習において , 学生も一般用医薬品が身近になる一方で炎の使い方や副 作用について専門家による介入や説明が必要となると考 えており，薬同師にとって「専門的な知識」が重要なス キルであると認識していることが明らかになった . しか し, 薬学部の講義では一般名で主に医療用医薬品を学習 するが, 一般用医薬品についての学習の機会は少ないと いう現状がある．アメリカにおける一般用医薬品に関す る教育の例として，アラバマ州サンフォード大学薬学部 では, 学部 4 年次までの間に 80 時間におよふ心講義と約 9 力月の臨床実習を行っている2).こうした教育を受け たアメリカの薬剤師は一般用医薬品選別の重要な役割を 果たす医療人として評価されている．これらを踏まえ， 今後の薬学部 6 年制教育においては一般用医薬品に関す る学習を含めた専門知識の養成がますます必要になると 考えられる .

さらに学生は, 薬阁師の重要なスキルとして専門的な 知識に加え，光の知識を活用した医薬品情報提供能力を 重視していることも明らかとなった。SGDにおいて医 薬品情報提供の際にデータベースを利用するとの提案が 
みられたが, 今後, 登録販売者の新設や消費者のセルフ メディケーションへの意識の高まりにより一般用医薬品 の役割の増大が予想され，最低限の情報提供が達成され るために情報のデータベース化が進むと考えられる．ア ンケートBにおいて, 薬剤師の役割として医療用医薬 品だけでなく一般用医薬品や食品などを含めた体系的な 知識が必要であるという意見がみられるように，データ ベースは一般用および医療用医薬品に加えて保健用食 品，一般食品などの情報も必要と考えられる . 実際にこ うしたニーズにあったデータベースを用いた取り組みも 行われており ，データベースを利用することで，予測 される有害事象の発生を服用前に回避できる可能性が期 待されている．

また，アンケートBにおいて，学生が薬剂師の役割 として「個々人に応じた薬を勧める能力」や「相談しや すい状況作り」を挙げており，画一的な情報提供のみで なく消費者との「コミュニケーション能力」の必要性を 考えていた . 飯嶋らの報告によると，保険薬局において は患者情報の入手方法として「患者との対話」(94.0\%)， 次いで「お薬手帳」(75.6\%)，「薬剂服用歴」(73.3\%)の順 であり")，さまざまな方法による情報収集が可能であ る．しかし，一般用医薬品を使用する消費者では薬剤服 用記録やお薬手帳の活用が少なく，一般用医薬品販売の 際には, 消費者との対話がより重要になると考えられ る.さらに学生が一般用医薬品販売における薬㓢師の役 割として登録販売者との情報交換，協力体制を指摘して おり，薬局における医療関係者間のコミュニケーション も重要になると認識していることが明らかとなったが, 病院におけるチーム医療や基礎研究におけるディスカッ ションなど, どの進路を考える学生にとっても必要にな るものと考えられる.オレゴン州立大学の薬学教育にお ける長期目標には「文章および口頭での高いコミュニ ケーション能力を身につけさせること」が含まれてい $ろ^{5}$. 同大学および日本の薬学部学生を対象にアンケー 卜を実施したところ，「現在のカリキュラムは患者/医療 従事者とのコミュニケーション能力が身につくか」とい う質問に対し，アメリカの薬学部学生は8 割以上が肯定 的な回答であったのに対し, 日本の薬学部学生は 8 割以 上が否定的な回答であった .このことから，臨床現場で 応用可能な能力を身につけるカリキュラムの設定が必要 になると考えられる.現在，薬学 6年制教育に向けて医 学および歯学の分野で取り入れられている客観的臨床能 力試験(OSCE : Objective Structured Clinical Examination) の導入が決定し，产の運用が検討されている．OSCEに おける模擬患者への対応という課題はコミュニケーショ ン教育の最終評価として, 学生の自己学習への意欲と患
者に対して真摰に向き合う姿勢を身につけることができ るとされるの . 最終評価としてのOSCE の運用に加え， コミュニケーションに関する講義の一環として自らの主 張と班としての結論が必要となる SGD を積極的に取り 入れることは有意義であると考えられる .

今回の千葉大学薬学部 3年次学生に対する SGD およ びアンケートから，身近に感じている一般用医薬品に関 する法改正について, 学生が关の利点と問題点, および 今後薬斉師の果たすべき役割について認識していること が明らかとなった . 一般用医薬品のリスク分類や登録販 売者の設置等一般用医薬品販売の状況が变化するなか で, 学生は薬剂師として医薬品に関与する意義や薬剂師 として果たせる役割を討論した．今後の薬齐師教育には 専門的な知識の習得に加えコミュニケーション能力の養 成も必要になると学生自身が認識したことから，SGD を通じた実習を積極的に取り入れることにより，これら を習得する意義を理解した上で薬学教育に臨むことが可 能になると考えられる .

謝辞 本研究に助成を賜りました財)一般用医薬品セルフメ ディケーション振興社団に深謝致します．

\section{引用文献}

1) 武政文彦, 特集 新しい一般用医薬品販売制度の有 効な実現に向けて 4 .今後望まれる一般用医薬品と は2)薬局薬㓢師の立場から : スイッチ OTC 薬を含 めて, 薬局 , 43，2459-2463 (2007).

2) 鍋島俊隆, 欧米の臨床薬学教育, 厚生労働科学研究 費補助金医薬品・医療機器レギュラトリーサイエン 又総合研究事業平成一六年度分担研究課題「海外に おける臨床薬学教育に関する調査研究」, 25-34 (2005).

3) 大嶋耐之, 武井政陛, 毎田千恵子, 宮本悦子，一般 用医薬品医薬情報データベースを用いた情報提供に ついて, 医療薬学, 31，457-463 (2005).

4) 飯嶋久志, 石野良和, 安藤秀人, 茂木博, 薬局にお ける患者情報の入手方法と活用に関する調査，医療 薬学 , 31，223-227 (2005).

5) 山田友子, 向後麻里, 木津純子, Teresa O' Sllivan, Wayne A. Kradjan, 木内祐二, 日本およびアメリカ の薬学教育カリキュラムの比較と薬学生の意識調査 - 日米 4大学における調査と薬学教育モデル・コア カリキュラムの解析一, 医療薬学, 31, 344-354 (2005).

6) 半谷眞七子, 松葉和久, 松井俊和, 薬学生の臨床コ ミュニケーション教育としての客観的臨床能力試験 (OSCE)の試みと光の評価，医療薬学，31，606-619 (2005). 